\title{
Effects of precipitation and restoration vegetation on soil erosion in a semi-arid environment in the Loess Plateau, China
}

\author{
Ji Zhou ${ }^{\mathrm{a}, \mathrm{b}}$, Bojie Fu ${ }^{\mathrm{a}, \mathrm{b}, *}$, Guangyao Gao ${ }^{\mathrm{a}, \mathrm{b}}$, Yihe Lü ${ }^{\mathrm{a}, \mathrm{b}}$, Yu Liu ${ }^{\mathrm{c}}$, Nan Lü ${ }^{\mathrm{a}, \mathrm{b}}$, Shuai Wang ${ }^{\mathrm{a}, \mathrm{b}}$ \\ a State Key Laboratory of Urban and Regional Ecology, Research Center for Eco-Environmental Sciences, Chinese Academy of Sciences, Beijing 100085, PR China \\ b Joint Center for Global Change Studies, Beijing 100875, PR China \\ c Key Laboratory of Ecosystem Network Observation and Modeling, Institute of Geographic Sciences and Natural Resources Research, Chinese Academy of Sciences, 100101, Beijing, PR China
}

\section{A R T I C L E I N F O}

Article history:

Received 6 January 2015

Received in revised form 18 August 2015

Accepted 24 August 2015

Available online 12 September 2015

\section{Keywords:}

Soil erosion

Restoration vegetation

The Loess Plateau

Structure equation modelling

\begin{abstract}
A B S T R A C T
Soil erosion is a critical environmental problem of the Loess Plateau, China. As an important project for soil and water conservation in the semi-arid environment, the Grain-for-Green extensively transformed a wide range of farmland into vegetated land after the 1980s. Yet, the effects of vegetation restoration on soil erosion reduction are not well understood. In this study, we monitored runoff and sediment yield at sites restored with six typical restoration vegetation types including shrubs (Armeniaca sibirica, Spiraea pubescens and Artemisia coparia), grasses (Andropogon), and shrub-grass-compounds (Andropogon and A. coparia) in the Loess Plateau. We employed structural equation modelling (SEM) to systematically analyze the relative effects of precipitation and vegetation on soil erosion. The results showed that the runoff and sediment yield at the grasslands were significantly higher than other cover types. The shrub cover had the strongest soil conservation capacity of all restoration vegetation. SEM results showed varying impacts of precipitation (i.e., total amount and erosive rainfall intensity) on runoff and soil erosion under different vegetation types owing to differences in canopy structure and surface litter layer. Our study quantitatively revealed the interactive effects of precipitation and vegetation on runoff and sediment, which may be beneficial to conserving available water and soil resources in the semiarid environment.
\end{abstract}

(c) 2015 Elsevier B.V. All rights reserved.

\section{Introduction}

Soil erosion is a serious and complex environmental problem worldwide (Portenga and Bierman 2011). It directly causes soil deterioration (Marques et al. 2008) and decreases land productivity (Lantican et al. 2003). It is mainly triggered by a combination of natural forces and anthropogenic activities. The eigenvalues of erosive precipitation and vegetation distribution patterns in a semi-arid environment are among the primary driving and preventive forces to soil erosion. Systematically comprehending the interactive effects of main influencing factors on soil erosion is a key step to conserve soil and water and assess the efficacy of soil erosion control practices in semi-arid regions (Fu et al. 2011).

Two typical conceptual models have been developed to represent the impacts of precipitation on runoff and sediment yield. The first kind of models emphasizes the role of the kinetic energy of erosive raindrops. Raindrops with kinetic energy that exceeds the threshold of soil erodibilitydetaches soil particles. The detached soil particles are the

\footnotetext{
* Corresponding author at: State Key Laboratory of Urban and Regional Ecology, Research Center for Eco-Environmental Sciences, Chinese Academy of Sciences, P. O. Box 2871, Beijing 100085, PR China.

E-mail address: bfu@rcees.ac.cn (B. Fu).
}

source of transportable sediments. In the revised universal soil loss equation (RUSLE), rainfall erosivity is an important contributing factor (Renard and Freimund 1994). This factor quantifies the kinetic energy of an erosive raindrop. The kinetic energy of erosive rainfall intensity was found to be the determinant of soil seal formation (Assouline and Ben-Hur 2006). The other type of conceptual models are built upon the formation of a soil seal after raindrop splashing which could effectively prevent infiltration and finally increase runoff.

On the other hand, vegetation has been widely reported to negatively correlate with runoff and sediment yield (Curran and Hession 2013; Fattet et al. 2011; García-Ruiz 2010; Gyssels et al. 2005; Puigdefábregas 2005). Vegetation type, spatial patterns, and their heterogeneous morphological characteristics in restoration land can have substantial impacts on soil erosion processes. Puigdefábregas et al. (1999) explored the importance of vegetated patches in minimizing soil erosion in semi-arid ecosystems. Plant spatial patterns can alter the source-sink erosion distribution, which was a precondition for describing the transporting route of runoff and sediment in a catchment or larger spatial scales (Bautista et al. 2007; Mayor et al. 2008; Puigdefábregas 2005). In a semi-arid environment, restoration vegetation with dense shrubs could effectively reduce runoff and sediment transport (García-Ruiz 2010). Forests showed the strongest ability to prevent soil erosion in the Loess Plateau (El Kateb et al. 2013). Some 
researchers (Burylo et al. 2011; Buttle and Farnsworth 2012; Fu et al. 2012; Mohammad and Adam 2010) observed that a mixed pattern of forests and shrubs would be optimal for inhibiting soil erosion.

The morphological properties of restoration vegetation play different roles on storing water and on controlling sediment yield. Interception (Ghimire et al. 2012; Wang et al. 2012) and absorption (Kurothe et al. 2014; Park et al. 2010) of throughfall are the substantial hydrological functions of canopy and litter layer in restoration vegetation. Wang et al. (2012) indicated the positive linear relationship between canopy storage capacity and leaf area index. Some interception models (Ghimire et al. 2012; Liu 1997; Liu 1998) explicitly use canopy structural information to quantify the complicated water balance related to canopy features. Canopy cover and plant height are two crucial variables that affect splash erosion in the Morgan-Finney model ( $\mathrm{Gu}$ et al. 2013; Morgan 2001). Additionally, various litter layer types, including leaf residues (Geißler et al. 2012) and a vegetation ash layer (Cerdà and Doerr 2008), play crucial roles in protecting the soil against splash erosion and improving infiltration during precipitation (Price et al. 2010; Woods and Balfour 2010).

Although the effects of precipitation and vegetation on soil erosion in semi-arid environments have been extensively studied, complex interactions among these influencing factors remain unquantified (Curran and Hession 2013; Hartanto et al. 2003; Molina et al. 2012). More advanced analytical methods should be used to explore their direct and indirect impacts and relative contributions to soil and water loss. Comparing with other multivariate analytical methods, structural equation modelling (SEM) is constructed on the complete body of specific and available knowledge (Grace 2006). The problem-oriented property of SEM combines concrete a priori knowledge with statistical analysis, and effectively estimates the strength of direct or indirect effects of multi-variables on the responses. Moreover, it could specifically determine the causal relationships between potential independent variables and responsive variables and consequently systematically examine the interactive effects of contributing factors exerting on the responsive results (Grace 2006). SEM has been applied to deal with many complex and challenging problems in ecological studies (Austin 2007; Larson and Grace 2004; Sutton-Grier et al. 2010; Texeira et al. 2012), but with few applications to study soil erosion problems (Chamizo et al. 2012).

In this paper, we monitored soil erosion under different heterogeneous restoration vegetation patterns in the Loess Plateau during a 4year period. We further employed the univariate regression and SEM methods to analyze the interactive effects of main influencing factors on runoff and sediment. The aims of this study were to: (1) estimate the variance of runoff and sediment response to vegetation type, (2) determine the contributions of precipitation and vegetation on soil erosion, and (3) partition and explain which factors are the most important in affecting erosive response in each of three vegetation types.

\section{Materials and methods}

\subsection{Site description}

The study was conducted in the Yangjuangou Catchment $\left(36^{\circ} 42^{\prime} \mathrm{N}\right.$, $109^{\circ} 31^{\prime} \mathrm{E}, 2.02 \mathrm{~km}^{2}$ ) in the central part of the Loess Plateau (Fig. 1A). The climate is typical semi-arid with an average annual rainfall of $535 \mathrm{~mm}$. There is an obvious rainy season from June to September with precipitation indicating significant inter-annual variability. Soil type is classified as Calcaric Cambisol whose weak structure is
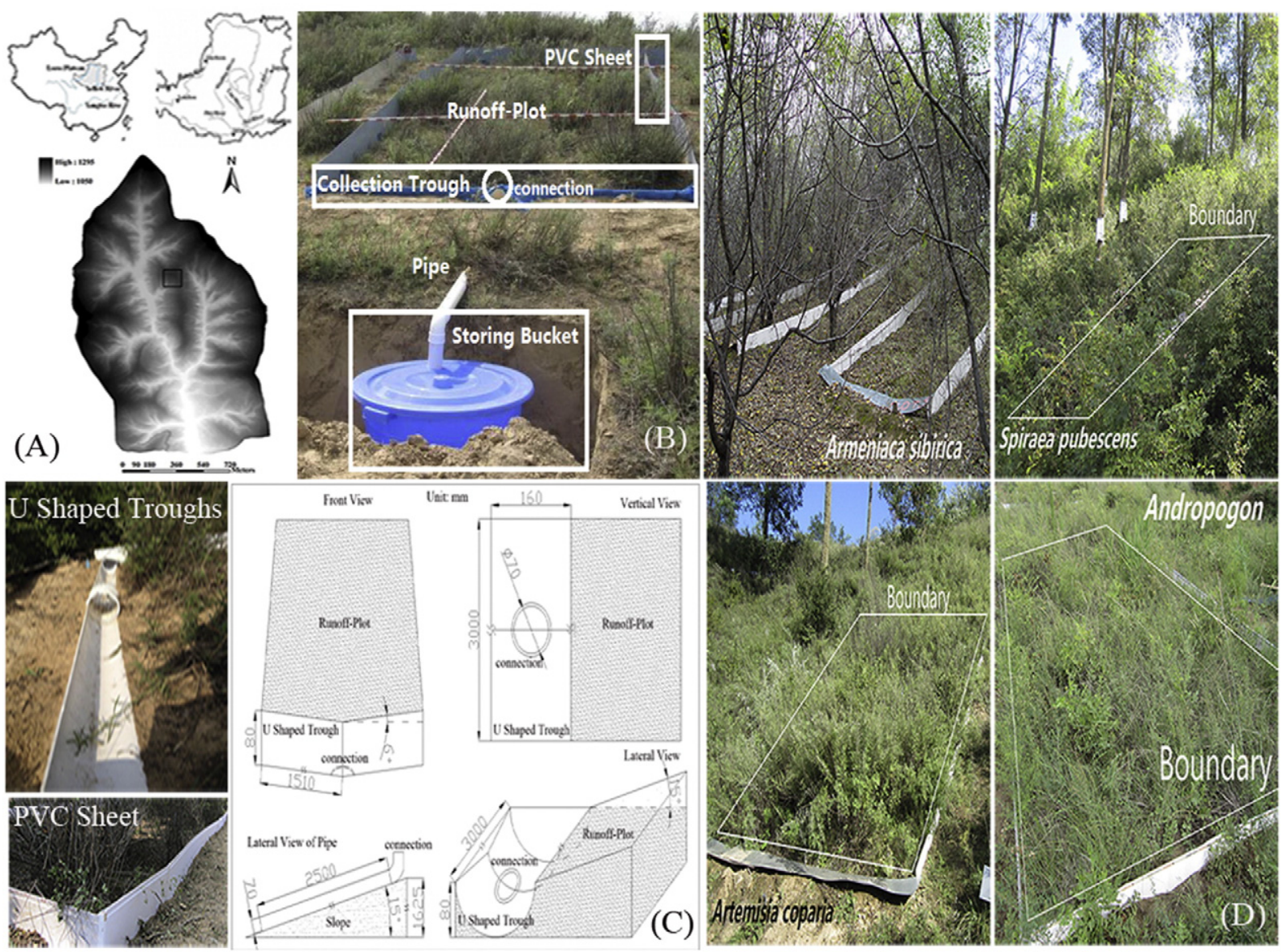

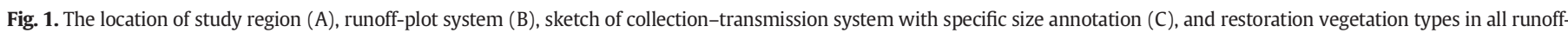
plots (D). 
Table 1

The characteristics of soil and restoration vegetation.

\begin{tabular}{|c|c|c|c|c|c|c|c|c|c|c|}
\hline \multirow{2}{*}{$\begin{array}{l}\text { Restoration } \\
\text { vegetation }\end{array}$} & \multicolumn{4}{|l|}{ Soil properties } & \multicolumn{4}{|c|}{ Vegetation properties } & \multirow{2}{*}{$\begin{array}{l}{ }^{\mathrm{f}} \mathrm{NYR} / \\
\mathrm{OY}\end{array}$} & \multirow[t]{2}{*}{${ }^{g}$ Others } \\
\hline & $\begin{array}{l}\text { Clay } \\
(\%)\end{array}$ & $\begin{array}{l}\text { Silt } \\
(\%)\end{array}$ & $\begin{array}{l}\text { Sand } \\
(\%)\end{array}$ & $\begin{array}{l}{ }^{\mathrm{a} D B D} \\
\left(\mathrm{~g} \cdot \mathrm{cm}^{-3}\right)\end{array}$ & $\begin{array}{l}\text { bLitter } \\
(\mathrm{cm})\end{array}$ & $\begin{array}{l}{ }^{\mathrm{c}} \text { Height/Crown/S } \\
(\mathrm{cm})\end{array}$ & $\begin{array}{l}{ }^{\mathrm{d}} \mathrm{Cov} / \mathrm{LAI} \\
(\%)\end{array}$ & $\begin{array}{l}{ }^{\mathrm{e}} \text { Biomass } \\
\left(\mathrm{g} \cdot \mathrm{cm}^{-2}\right)\end{array}$ & & \\
\hline (L1) & $11.07 \pm 2.43$ & $26.11 \pm 1.50$ & $62.82 \pm 0.94$ & $1.28 \pm 0.08$ & 1.2 & $>200 />200 / \approx 200$ & $60-85 / \times$ & $\times$ & $20 / 4$ & $\times$ \\
\hline (L2) & $11.98 \pm 3.05$ & $25.24 \pm 3.84$ & $62.78 \pm 4.51$ & $1.16 \pm 0.12$ & 3.4 & $128.3 / 80.6 / 46.7$ & $65-90 / 2.31$ & 423.4 & $20 / 4$ & $\times$ \\
\hline (L3) & $8.21 \pm 2.01$ & $26.37 \pm 1.74$ & $65.42 \pm 2.23$ & $1.22 \pm 0.07$ & $\approx 0$ & $0 / 0 / 0$ & $50-85 / 1.20$ & 65.4 & $20 / 4$ & $\begin{array}{l}\text { Setaria viridis, Heteropappus altaicus, } \\
\text { Melilotus albus }\end{array}$ \\
\hline (L4) & $9.54 \pm 1.48$ & $26.72 \pm 2.87$ & $63.74 \pm 3.24$ & $1.23 \pm 0.10$ & 1.8 & $61.8 / 63.4 / 0$ & $65-90 / 1.78$ & 218.5 & $20 / 2$ & $\times$ \\
\hline (L5) & $8.48 \pm 2.14$ & $25.28 \pm 1.98$ & $66.24 \pm 2.24$ & $1.26 \pm 0.11$ & $\approx 0$ & $32.4 / 0 / 0$ & $60-85 / 1.22$ & 68.9 & $20 / 2$ & $\times$ \\
\hline (L6) & $10.04 \pm 1.06$ & $24.58 \pm 1.37$ & $65.38 \pm 1.58$ & $1.18 \pm 0.21$ & 2.0 & $60.2 / 58.3 / 0$ & $75-90 / 1.74$ & 251.1 & $20 / 2$ & $\begin{array}{l}\text { Artemisia dalai-lamae, Incarvillea } \\
\text { sinensis, Viola dissecta, }\end{array}$ \\
\hline
\end{tabular}

a Dry bulk density.

b Average thickness of litter layer.

c The average height, crown width and stem length (short for S).

d The coverage and leaf area index.

e Average aboveground biomass.

${ }^{f}$ NYR is short for number of years since restoration, OY is short for observational years.

$\mathrm{g}$ Other main species existing in L3 and L6, both of whose dominant populations were Andropogon and Artemisia coparia respectively.

vulnerable to water erosion (Liu et al. 2012). Restoration in this area started in 1980s, with nearly all farmland on the slopes being restored by anthropogenic activities or abandoned for natural recovery. The main artificial vegetation species include Robinia pseudoacacia Linn, Platycladus orientalis, Lespedeza davurica, and Amorpha fruticosa. Naturally restored areas contain Armeniaca sibirica, Spiraea pubescens, Andropogon, Artemisia coparia, etc.

\subsection{Field experiment}

We monitored soil erosion under six restoration vegetation types: $A$. sibirica (L1), S. pubescens (L2), Andropogon C (L3), A. coparia (L4), Andropogon (L5) and A. coparia C (L6). The capital latter C appended to the vegetation species name indicates that, except for the dominant species, the corresponding restoration vegetation consists of more than other two obvious species. For instance, Andropogon $\mathrm{C}$ is dominated by Andropogon but has the clear presence of Setaria viridis, Heteropappus altaicus and Melilotus albus. The erosion monitoring period of L1, L2 and L3 lasted for four rainy seasons (2008, 2009, 2011 and 2012). In 2011, we added L4, L5 and L6, and they were monitored for two rainy seasons (2011 and 2012). All the vegetation had been restored for nearly 20 years, and was distributed on a southwestnortheast hillslope with a $26.8 \%$ aspect.

In each vegetation type, three $3 \mathrm{~m}$ by $10 \mathrm{~m}$ closed runoff plots were established. In total, there were eighteen runoff plots with similar slope gradient, aspect and altitude. The boundaries of the runoff plots on two sides along the slope and upslope were fenced by impervious, perpendicularly inserted PVC sheets (approximately $50 \mathrm{~cm}$ deep). The thickness of PVC boundaries was only $2 \mathrm{~mm}$ which could hardly influence surface water flow on both sides of a runoff plot (Fig. 1B). A collection system consisting of two interconnected $U$ shaped troughs was installed at the bottom boundary of each runoff plot (Fig. 1C). The inner side (i.e., toward the enclosed runoff plot) of the two U shaped troughs was tamped by compact soil to allow it to be tightly embedded in the soil. The collected materials in the troughs were channeled into a plastic storage bucket via a PVC pipe. The pipe had an inner diameter of $70 \mathrm{~mm}$ and was laid with a slope of $15^{\circ}$. This design is effective in transmitting the runoff and sediment into the pipe and storage bucket through gravity as well as in preventing backflow from the runoff plot. Previous studies showed that this collection-transmission system is enough to

Table 2

The interpretation of goodness-of-fit-indices (GOFIs) system in structural equation modelling.

\begin{tabular}{|c|c|c|c|c|}
\hline $\begin{array}{l}\text { GOFIs } \\
\text { component }\end{array}$ & Fitting Type & Value & Meaning & Reference \\
\hline CMIN & $\begin{array}{l}\text { Absolute fit } \\
\text { measurement }\end{array}$ & $\begin{array}{l}\text { None } \\
\text { range }\end{array}$ & $\begin{array}{l}\text { Full name: minimum fit function chi-square value } \\
\text { The value of CMIN was smaller, and has a better fit between a hypothetical model (prior model) and } \\
\text { measurement data. The ideal number sample in a chi-square test ranged from } 100 \text { to } 200 .\end{array}$ & Rigdon (1995) \\
\hline CMIN-P & $\begin{array}{l}\text { Absolute fit } \\
\text { measurement }\end{array}$ & $(0.05,1)$ & $\begin{array}{l}\text { Full name: significance probability value of CMIN } \\
\text { In the significance test of CMIN, if the CMIN-P }<0.05 \text {, then it rejects the null hypothesis which means that the } \\
\text { covariance matrix of sample data cannot fit the covariance matrix of the hypothesis model or prior model. If the } \\
\text { CMIN-P }>0.05 \text {, then it accepts the null hypothesis, which means that the hypothesis model or prior model fits } \\
\text { the measurement data. }\end{array}$ & Wu (2010) \\
\hline RMSEA & $\begin{array}{l}\text { Absolute fit } \\
\text { measurement }\end{array}$ & $(0,0.08)$ & $\begin{array}{l}\text { Full name: root mean square error of approximation } \\
\text { RMSEA represents the value of population discrepancy function based on the consideration of the degree of } \\
\text { freedom and the complexity of a prior model. Theoretically, if RMSEA } \in(0.1,+\infty) \text {, the fitness of models is poor, } \\
\text { which indicates a need to modify it; if RMSEA } \in(0.05,0.08) \text {, then the fitness of models is mediocre; if RMSEA } \\
(-\infty, 0.05) \text {, the fitness is good, and if RMSEA } \in(-\infty, 0.01) \text {, the fitness is outstanding. }\end{array}$ & $\begin{array}{l}\text { MacCallum } \\
\text { et al. (1996) }\end{array}$ \\
\hline NNFI & $\begin{array}{l}\text { Incremental fit } \\
\text { measurement }\end{array}$ & $(0.90,1)$ & $\begin{array}{l}\text { Full name: non-normed fix index or Tucker-Lewis index } \\
\text { NNFI represents the fitness of a prior model and a null hypothesis model; moreover, it further considers the } \\
\text { complexity of a prior model and the degree of freedom of the two comparative models. If the value of NNFI was } \\
\text { more close to } 1 \text {, the fitness of the model is more outstanding. }\end{array}$ & $\begin{array}{l}\text { Bentler and } \\
\text { Yuan (1999); } \\
\text { Bentler and } \\
\text { Bonet (1980) }\end{array}$ \\
\hline CFI & $\begin{array}{l}\text { Incremental fit } \\
\text { measurement }\end{array}$ & $(0.81,1)$ & $\begin{array}{l}\text { Full name: comparative fit index } \\
\text { CFI represents the improvement of the non-centrality parameters of measurement data, when the prior model } \\
\text { changed from a limited model to a saturated model. If the value of CFI was more close to } 1 \text {, the non-centrality of } \\
\text { the measured data was more effectively improved, which means the fitness of the model is more outstanding. }\end{array}$ & $\begin{array}{l}\text { Bentler and } \\
\text { Yuan (1999); } \\
\text { Bentler and } \\
\text { Bonet (1980); }\end{array}$ \\
\hline
\end{tabular}


Prior Model

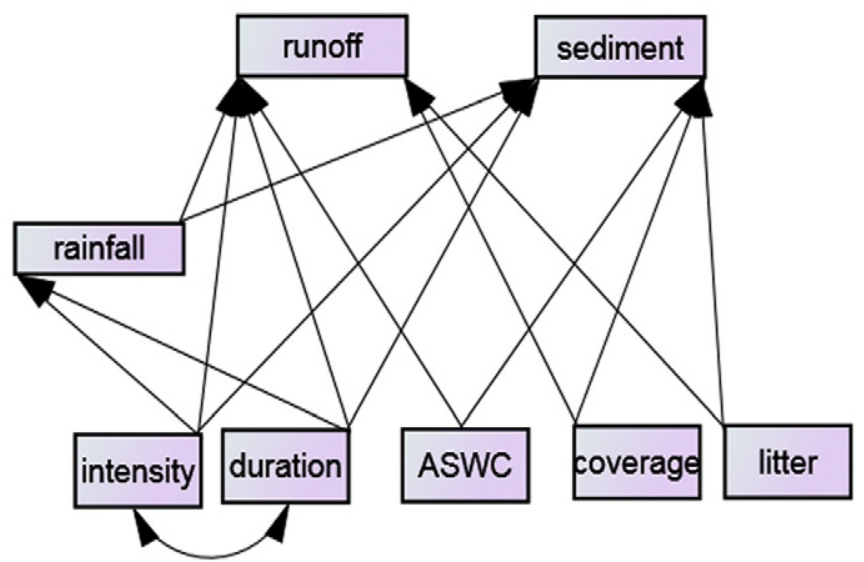

Fig. 2. The a priori SEM indicating the causal relationship among characteristics of rainfall, soil moisture, and morphological properties of restoration vegetation.

deal with a theoretical 17 liter per second amount of flow and has a capacity strong enough to transmit the peak runoff and sediment generated from the runoff plots with relatively high restoration vegetation cover in the Loess Plateau (Liu et al. 2012).

After each erosive rainfall event, we first brushed the transported sediment deposited in the collection trough into collecting bottles. All the runoff and sediment in the storage bucket were collected and the runoff volume measured. The sediment in the water was separated after settling the water for $24 \mathrm{~h}$, and the sediment was dried at $105^{\circ} \mathrm{C}$ over $8 \mathrm{~h}$ and weighed.

Precipitation was measured using two tipping bucket rain gauges with an accuracy of $0.2 \mathrm{~mm}$. The main properties of soil and plants in all restoration vegetation sites were measured (Table 1 ). The soil volumetric water contents at all sites were measured every three days over the monitoring period by TDR-300 Soil Moisture Meter (Spectrum Technologies, Inc., Aurora, Illinois, USA). The infiltration capacity of the sites were measured by a Model 2800 K1 Guelph Permeameter (Soilmoisture Equipment Corp., Santa Barbara, CA, USA).

\subsection{Statistical analyses}

To investigate the impacts of the length or inter-annual variability of observations on our results, we regrouped our observations for further analysis. Group 1 referred to the sites that were observed during four rainy seasons (i.e., L1, L2 and L3). Group 2 contained the sites with only two years of observations (i.e., L4, L5, and L6). Finally, Group 3 pooled all the sites (L1 to L6) but only observations obtained during the common observation period (i.e., 2011 and 2012) were used for analysis. For convenience, we refer to these groups as Group Long, Group Short, and Group Mixed, respectively, hereafter. The observed data were analyzed using three approaches. First, one-way analysis of variance (ANOVA) was employed to compare the differences in soil erosion responses of vegetation types. Second, bivariate correlation analysis was applied to determine the correlative relationship between the erosive response and the main influencing factors. The results indicate the possible effects of all measured influencing factors on soil erosion. Third, the structural equation modelling (SEM) approach, as an improvement of the correlation analysis, was conducted to analyze comprehensive effects of precipitation and vegetation on soil erosion. Based on the modification of a goodness-of-fit-indices system (GOFIs) in a-priori SEM (Table 2), the multiple causal effects of soil erosion could be partitioned and determined by a revised SEM. Six influencing factors (precipitation, intensity and duration of erosive rainfall events, average coverage and litter layer thickness of restoration vegetation, and antecedent soil moisture content (ASWC)) were the observed independent variables of normalized runoff and sediment yield in the a priori model (Fig. 2). The whole revision processes of initial prior SEM models were indicated in Table 3. The estimation of the GOFIs system demonstrated that the revised and accepted SEM could have higher probability and plausibility to reflect the interactive causal effects of precipitation and restoration vegetation on runoff and sediment. SEM development and analysis was performed using AMOS 21.0 software (SPSS Inc.).

\section{Results}

\subsection{ANOVA: impacts of restoration vegetation type}

The results of significant difference analysis of runoff and sediment yield in Group Long (Fig. 3A), Group Short (Fig. 3B) and Group Mixed

Table 3

The revision process of initial prior SEM.

\begin{tabular}{|c|c|c|c|c|c|c|c|}
\hline \multirow[t]{2}{*}{ Initial prior SEM } & \multirow[t]{2}{*}{ Revision process of SEM model } & \multirow{2}{*}{$\begin{array}{l}\text { Number } \\
\text { of paths }\end{array}$} & \multicolumn{4}{|c|}{ Goodness of fit indices system (GOFIs) } & \multirow[t]{2}{*}{ Decision $^{\mathrm{e}}$} \\
\hline & & & CMIN-P & RMESE & NNFI & CFI & \\
\hline Group Long (L1-L3) & Global initial saturated mode ${ }^{a}$ & 14 & $<0.05$ & Poor & $>1$ & $>1$ & Reject \\
\hline \multirow[t]{4}{*}{189 samples } & Remove the ASWC to runoff ${ }^{\mathrm{b}}$ & 13 & $<0.05$ & Poor & $(0.90,1)$ & $(0.81,1)$ & Reject \\
\hline & Remove the ASWC to sediment & 13 & 0.062 & Poor & $(0.90,1)$ & $(0.81,1)$ & Reject \\
\hline & Remove the ASWC to soil erosion & 12 & 0.281 & Good & $(0.90,1)$ & $(0.81,1)$ & Accept \\
\hline & Remove the third path ${ }^{\mathrm{c}}$ & $<12$ & $<0.05$ & $\mathrm{P}^{\mathrm{d}} / \mathrm{M}$ & $(0.90,1)$ & $(0.81,1)$ & Reject \\
\hline Group Short (L4-L6) & Global initial saturated mode & 14 & $<0.05$ & Poor & $>1$ & $>1$ & Reject \\
\hline \multirow[t]{4}{*}{108 samples } & Remove the ASWC to runoff & 13 & $<0.05$ & Poor & $(0.90,1)$ & $>1$ & Reject \\
\hline & Remove the ASWC to sediment & 13 & $<0.05$ & Mediocre & $(0.90,1)$ & $(0.81,1)$ & Reject \\
\hline & Remove the ASWC to soil erosion & 12 & 0.375 & Mediocre & $(0.90,1)$ & $(0.81,1)$ & Accept \\
\hline & Remove the third path & $<12$ & $<0.05$ & $\mathrm{P} / \mathrm{M}$ & $(0.90,1)$ & $(0.81,1)$ & Reject \\
\hline Group Mixed (L1-L6) & Global initial saturated mode & 14 & $<0.05$ & Poor & $>1$ & $>1$ & Reject \\
\hline \multirow[t]{4}{*}{216 samples } & Remove the ASWC to runoff & 13 & $<0.05$ & Poor & $(0.90,1)$ & $(0.81,1)$ & Reject \\
\hline & Remove the ASWC to sediment & 13 & 0.071 & Poor & $(0.90,1)$ & $>1$ & Reject \\
\hline & Remove the ASWC to soil erosion & 12 & 0.414 & Mediocre & $(0.90,1)$ & $(0.81,1)$ & Accept \\
\hline & Remove the third path & $<12$ & $<0.05$ & $\mathrm{P} / \mathrm{M}$ & $(0.90,1)$ & $(0.81,1)$ & Reject \\
\hline
\end{tabular}

The characteristics of finally revised and accepted SEM in three groups were stressed by the bold words.

a The global initial saturated mode includes six variables-precipitation, intensity and duration of rainfall, antecedent soil water content (ASWC), thickness of litter layer and coverage of restoration vegetation in Group 1, all of which have path directing to the runoff and sediment yield in the SEM.

b Removing the path of ASWC directing to the runoff.

c Removing the third path of other variables directing to the runoff or sediment.

d $\mathrm{P} / \mathrm{M}$ means poor or mediocre.

e Whether the revised SEM should be accepted or rejected depends on whether the values of components in GOIFs should be satisfied with the range shown in Table 2 or not. 

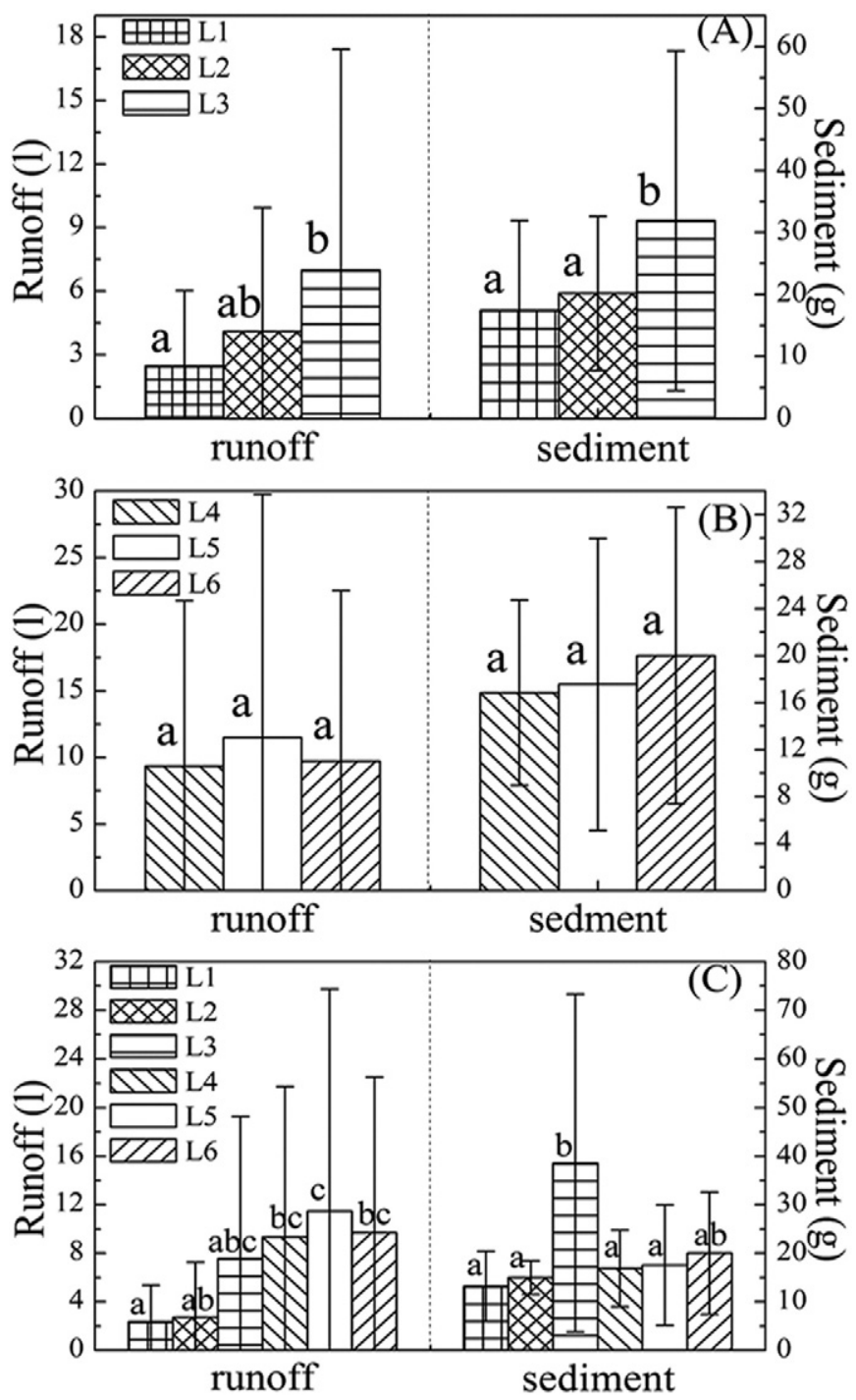

Fig. 3. Comparison of average runoff and sediment across sites: Group Long (L1-L3) (A), Group Short (L4-L6) (B), and Group Mixed (L1-L6) (C). Different letters in the figure indicate a significant difference at the $p<0.05$, determined by Tukey's HSD.

(Fig. 3C) are shown in Fig. 3. Within Group Long, the average runoff at L3 was approximately $7.5 \mathrm{l}$, higher than those covered by the other two vegetation types. The difference between L1 and L3 was significant $(\mathrm{p}=0.05)$. Similarly, the mean sediment yield at L3 (approximately
$30 \mathrm{~g}$ ) was the highest among the three restoration vegetation in Group Long. Within Group Short, the average runoff at L5 (about 11 l) was the highest. However, there was no significant difference in runoff among the three vegetation types. Although the mean sediment yield at L6 (about $20 \mathrm{~g}$ ) was slightly larger than those under the two other vegetation types, the differences among L4, L5 and L6 were not significantly different. In the Group Mixed, the average runoff values at L5 (roughly 121 ) and L1 (roughly 21 ) were the highest and lowest among all sites, and there was no significant difference of runoff between L4 and L6. Generally, it seems that runoff was more easily generated in Group Short plots (L4-L5) than in Group Long ones (L1-L3). Additionally, except for the significantly higher sediment yield (approximately $40 \mathrm{~g}$ ) at L3 than the rest of the plots, there was no significant difference of sediment generation among other sites. Consequently, the soil erosive responses at L3 and L5, both of which represented restoration with grasses, were relatively larger than other restoration vegetation types.

\subsection{Correlations between erosive responses and influencing factors}

The correlations between erosive responses and the measured six impacting factors at all sites are shown in Table 4. The precipitation and duration were positively and negatively correlated with the erosive responses, respectively. However, the correlations were not significant. The intensity of erosive rainfall positively correlated with the runoff and sediment with significance almost under all vegetation types (except at L3 which as not significant). The thickness of the litter layer was not significantly correlated with the runoff and sediment at all sites. The correlations between plant coverage and erosive responses were more complex. In Group Long (L1-L3), only the coverage negatively correlated with sediment yield significantly at L2. In Group Short (L4-L6), the coverage at L4 negatively correlated with the runoff and sediment yield significantly. The correlation between initial soil moisture and soil erosion was positive but not significant. These results probably implied that intensity was the strongest directly influencing factors that trigger the erosive responses at all sites, and the effects of litter layer and coverage may be more complicated under various vegetation types, begging for further partitioning of the causal effects of erosive response.

\subsection{Causal analysis from SEM}

The revised SEM describing the effects of five influencing factors on soil erosion based on observations from Group Long (L1-L3) is indicated in Fig. 4. The path coefficients indicated that the precipitation over the four rainy seasons exerted similar or stronger positive effects on runoff ( path coefficient $=0.53$ ) and sediment transport (path coefficient $=$ 0.48 ) than rainfall intensity. This implied that erosive precipitation could probably be the most important driving force to runoff and

Table 4

Correlations between soil erosion and influencing factors in different restoration vegetation.

\begin{tabular}{|c|c|c|c|c|c|c|c|c|c|}
\hline Code & Sample size & Erosive responses & Runoff & precipitation & duration & intensity & ASWC $^{\mathrm{a}}$ & Litter layer & Coverage \\
\hline \multirow[t]{2}{*}{ L1 } & \multirow[t]{2}{*}{63} & Runoff & - & $0.437^{*}$ & -0.243 & $0.460^{*}$ & 0.111 & -0.324 & 0.066 \\
\hline & & Sediment & $0.806^{* *}$ & 0.284 & -0.429 & $0.740^{* *}$ & 0.106 & -0.425 & 0.107 \\
\hline \multirow[t]{2}{*}{ L2 } & \multirow[t]{2}{*}{63} & Runoff & - & 0.210 & -0.257 & $0.581^{*}$ & 0.223 & -0.342 & -0.414 \\
\hline & & Sediment & $0.451^{*}$ & 0.047 & $-0.492^{*}$ & $0.478^{*}$ & 0.101 & -0.401 & $-0.451^{*}$ \\
\hline \multirow[t]{2}{*}{ L3 } & \multirow[t]{2}{*}{63} & Runoff & - & 0.362 & -0.274 & 0.381 & 0.084 & 0.008 & 0.035 \\
\hline & & Sediment & $0.835^{* *}$ & 0.305 & -0.386 & $0.496^{*}$ & 0.012 & -0.089 & 0.004 \\
\hline \multirow[t]{2}{*}{ L4 } & \multirow[t]{2}{*}{36} & Runoff & - & 0.326 & -0.485 & $0.709^{* *}$ & 0.259 & -0.403 & $-0.607^{*}$ \\
\hline & & Sediment & $0.821^{* *}$ & 0.357 & -0.479 & $0.833^{* *}$ & 0.088 & -0.332 & $-0.663^{*}$ \\
\hline \multirow[t]{2}{*}{ L5 } & \multirow[t]{2}{*}{36} & Runoff & - & 0.460 & -0.372 & $0.823^{* *}$ & 0.140 & -0.060 & -0.111 \\
\hline & & Sediment & $0.768^{* *}$ & 0.351 & -0.471 & $0.787^{* *}$ & 0.028 & -0.205 & $-0.430^{*}$ \\
\hline \multirow[t]{2}{*}{ L6 } & \multirow[t]{2}{*}{36} & Runoff & - & 0.416 & -0.396 & $0.809^{* *}$ & 0.080 & -0.378 & -0.319 \\
\hline & & Sediment & $0.823^{* *}$ & 0.319 & -0.486 & $0.703^{*}$ & 0.089 & -0.361 & -0.325 \\
\hline
\end{tabular}

* Significant level $\mathrm{p}<0.05$.

** Significant level $\mathrm{p}<0.01$.

a ASWC (antecedent soil water content). 
(A)
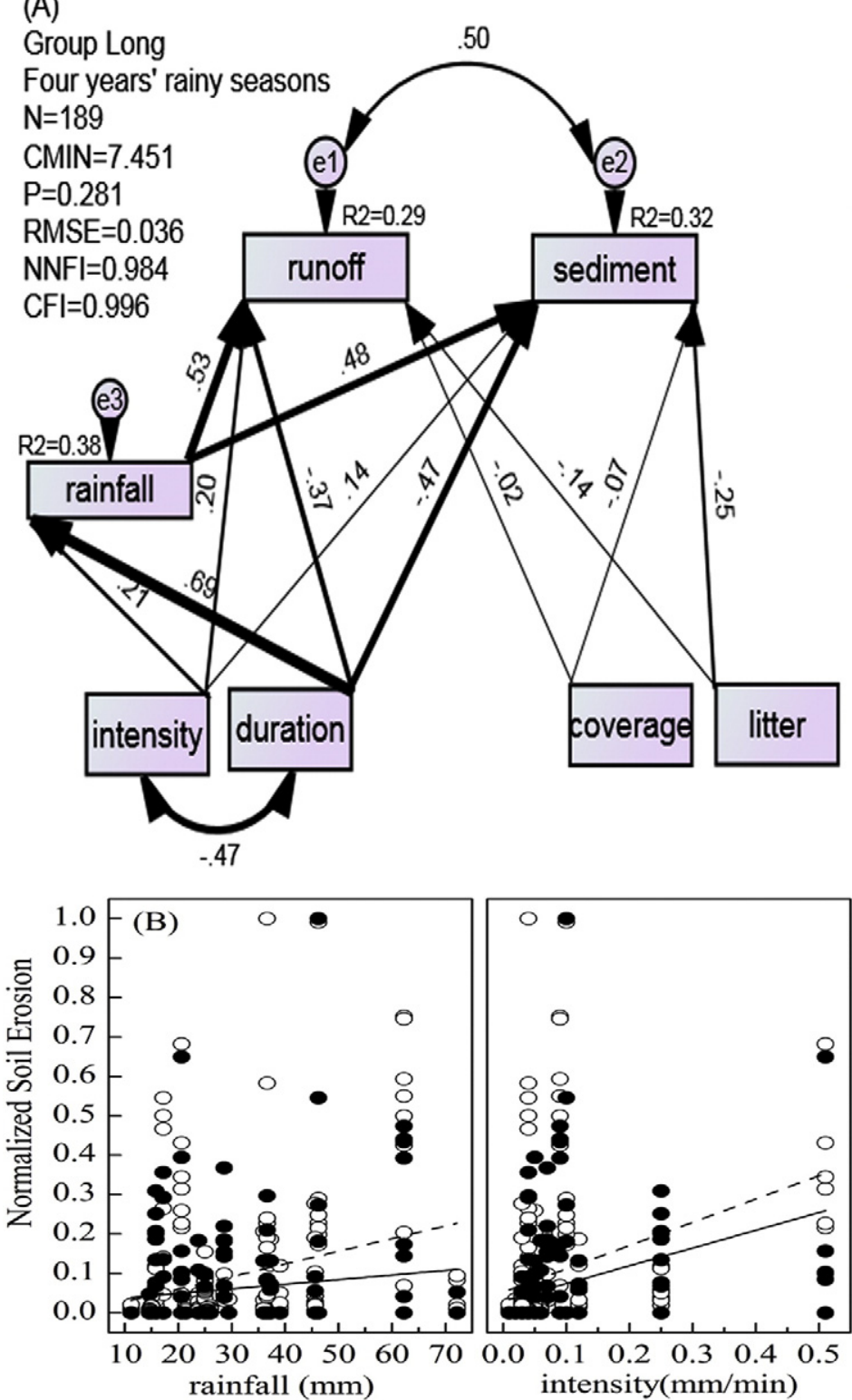
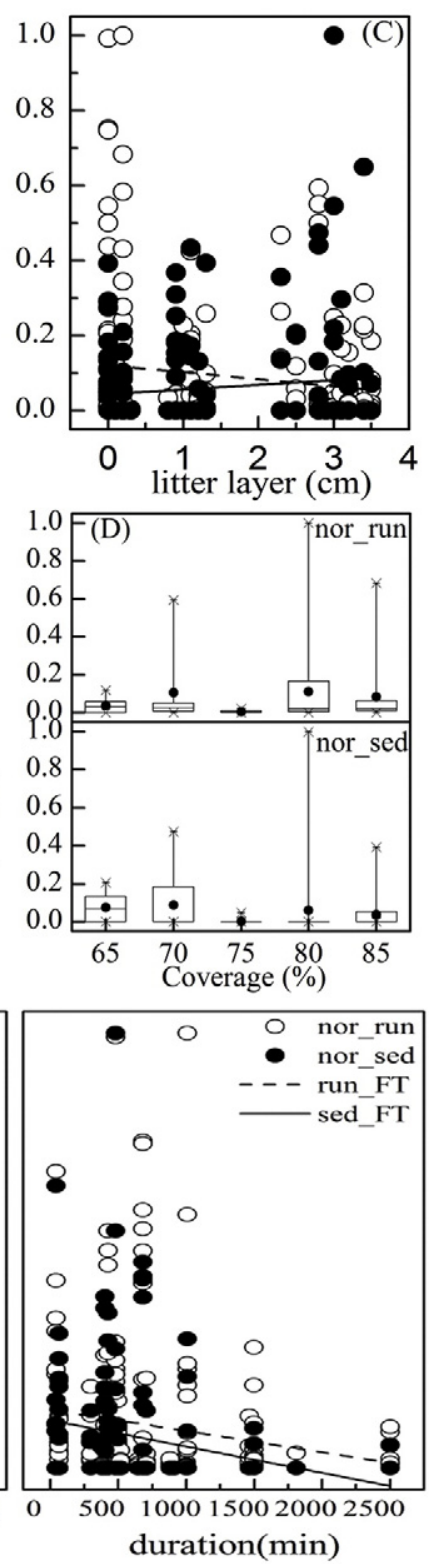

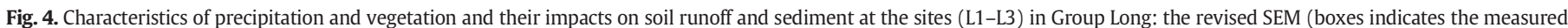

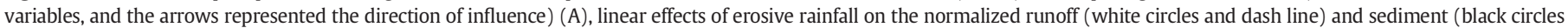

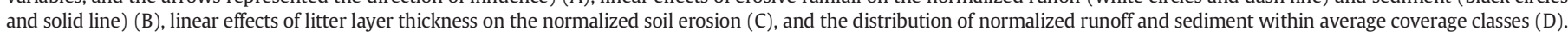

sediment for Group Long. Runoff and sediment were more strongly and positively mediated by the thickness of the litter layer than by the coverage of the restoration vegetation. Finally, SEM showed that all direct effects included in this study could explain $29 \%$ and $32 \%$ of the variance in runoff and sediment, respectively.

Fig. 5 shows the results from Group Short. The results suggested that both precipitation and intensity of erosive rainfall exerted approximately similar positive effects on runoff and sediment. Specifically, although the direct positive influence of precipitation (path coefficient $=0.25$ ) on runoff was weaker than that of rainfall intensity (path coefficient $=$ 0.46 ), the positive effect of sediment transport mediated by precipitation (path coefficient $=0.33$ ) was slightly higher than that by intensity (path coefficient $=0.29$ ). Additionally, the average coverage exerted stronger directly negative effects on runoff and sediment than the thickness of the litter layer. The negative effects of restoration vegetation in Group Short were in contrast to the results in Group Long, which might imply that the complex effects of plant morphological properties on soil erosion under different vegetation types might change with the length of observation. Greater than half of the variance in runoff (54\%) and sediment (52\%) could be explained by the five influencing variables in the revised SEM. Fig. 5C also showed the insignificant negative linear effects of the litter layer on the normalized runoff and sediment, similar to the results of SEM.

The revised SEM in Fig. 6, developed for Group Mixed, demonstrated more complex causal relationships between soil erosion and its influencing factors than those for Group Long and Group Short in Figs. 4 and 5, respectively. The precipitation and intensity of erosive rainfall exerted equal positive effects (path coefficient $=0.29$ ) on runoff. The sediment transport was strongly and positively mediated by the erosive intensity (path coefficient $=0.59$ ) than by precipitation and duration. This result might imply that rainfall intensity could be the most crucial factor to trigger soil erosion at all restoration sites. Meanwhile, as shown in Fig. 6, the average thickness of the litter layer and coverage also played roles on soil and water conservation. Specifically, the direct 


\section{(A)}
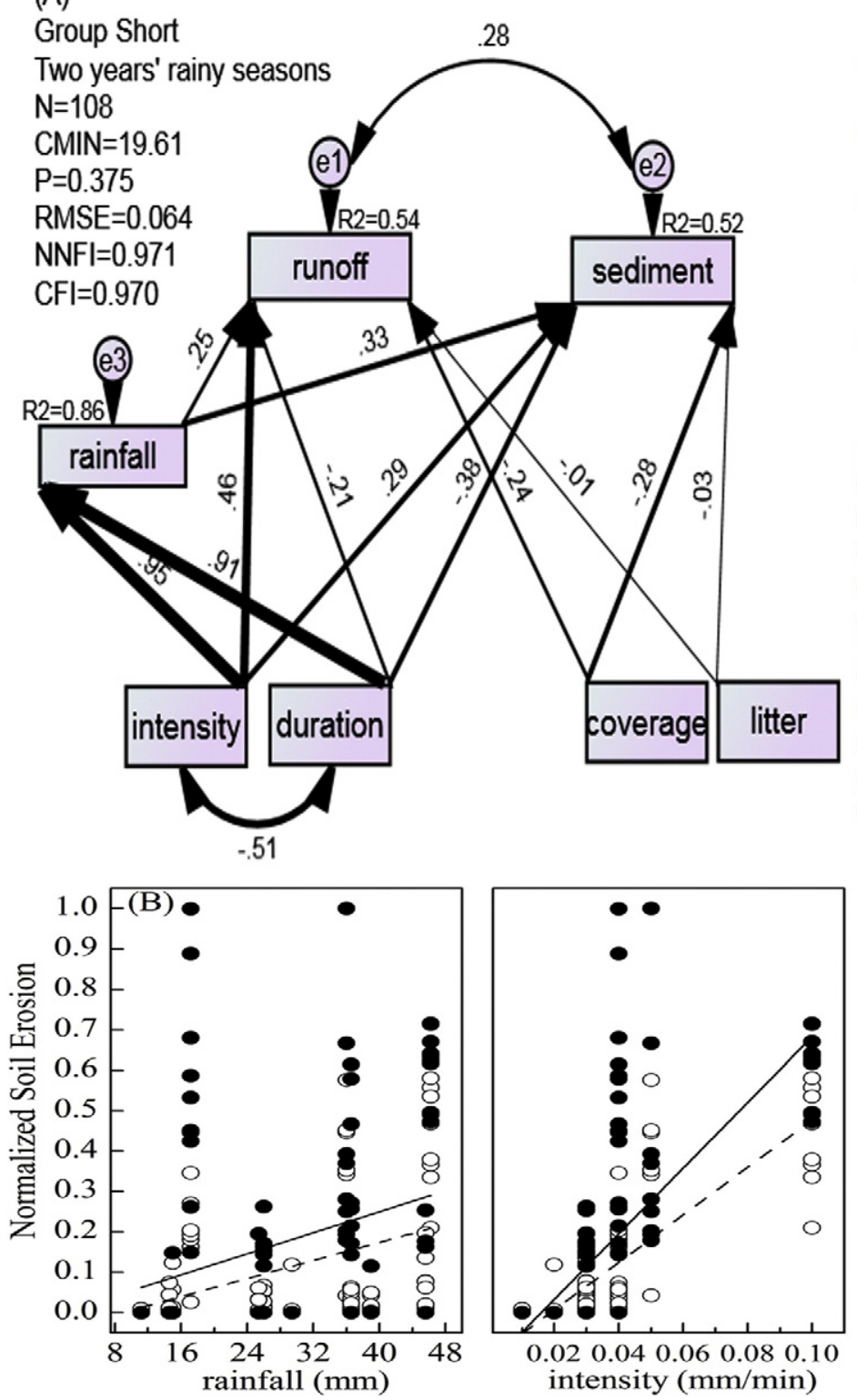
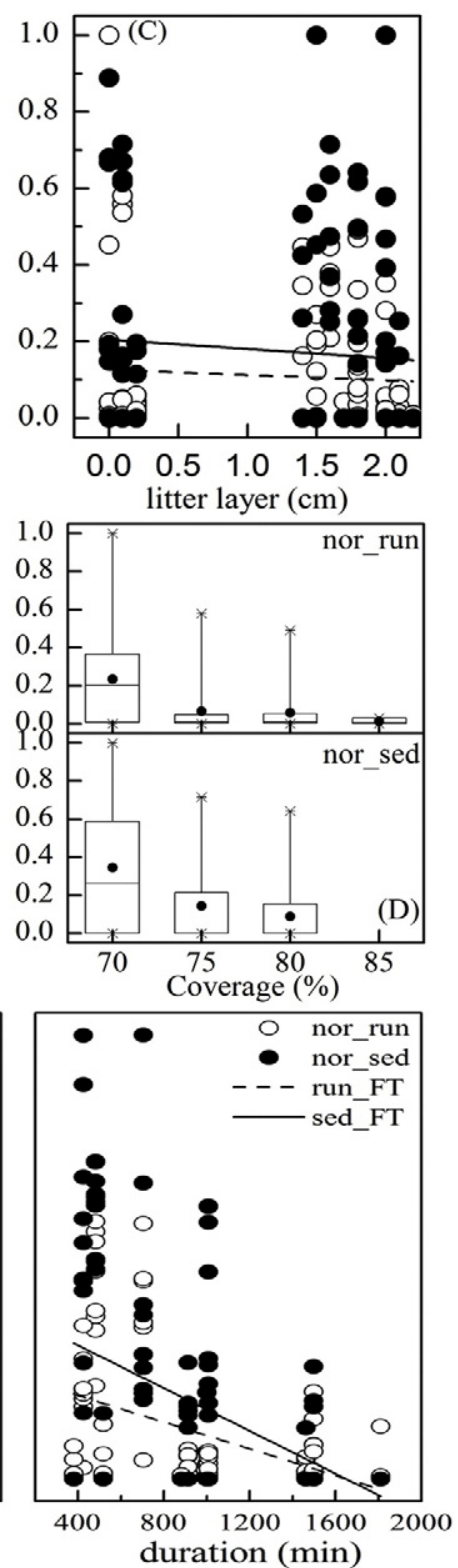

Fig. 5. The same as Fig. 4, except for Group Short.

negative effect of average coverage was stronger than that of the thickness of the litter layer on runoff. However, the litter layer exerted stronger negative effects on sediment transport than average coverage.

\section{Discussion}

To analyze the effects of various driving forces on soil erosion, this study employed two approaches. The first is to quantify the correlations between soil erosion and its main influencing factors at different sites through traditional univariate analysis (Table 4). The other is to further explore the interactive and causal effects of driving variables on soil erosion using the SEM method (Fig. 4-6). The SEM could be considered as an improvement of univariate analysis, with the theoretical basis for SEM construction concentrating on a-priori knowledge related to the specific problem rather than generally on the null hypothesis testing related to the statistical theory (Grace 2006). These two methods generated different insights. For example, ASWC was positively correlated with runoff and sediment yield according to correlation analysis (Table 4). However, it was excluded as an influencing factor in the final SEM. The exclusion of ASWC in the accepted SEM implies that the direct influence of soil moisture on erosion processes could be neglected. It might be related to the fact that soil moisture content has a more complicated and dynamic hydrological behavior exerting upon the soil matrix system than other influencing factors (Rodriguez-Iturbe et al. 2001). This can lead to more variable causal effects of soil water content on runoff and sediment, resulting in the ASWC being not satisfied with the requirement of GOFIs testing in SEM (Table 3).

The morphological characteristics among the three restoration vegetation types in Group Long reflected vegetation heterogeneity and hierarchy (Table 1). Most of the precipitation and intensity of erosive rainfall over the monitoring period were less than $25 \mathrm{~mm}$ and $0.02 \mathrm{~mm} / \mathrm{min}$, respectively (Fig. 7). SEM for Group Long indicated that the precipitation of erosive rainfall and the thickness of the litter layer were the prime factors triggering and controlling soil erosion in these systems. Soil conservation resulted in an obvious litter layer structure for the Group Long sites, especially at L2. The thickness of the litter layer could increase the shear strength of the soil surface, inhibit soil detachment, and supply more permeating channels in soils that decrease runoff coefficient (Bodí et al. 2012; Cerdà and Doerr 2008; Woods and Balfour 2010). In the same study area, Liu et al. (2012) also considered 

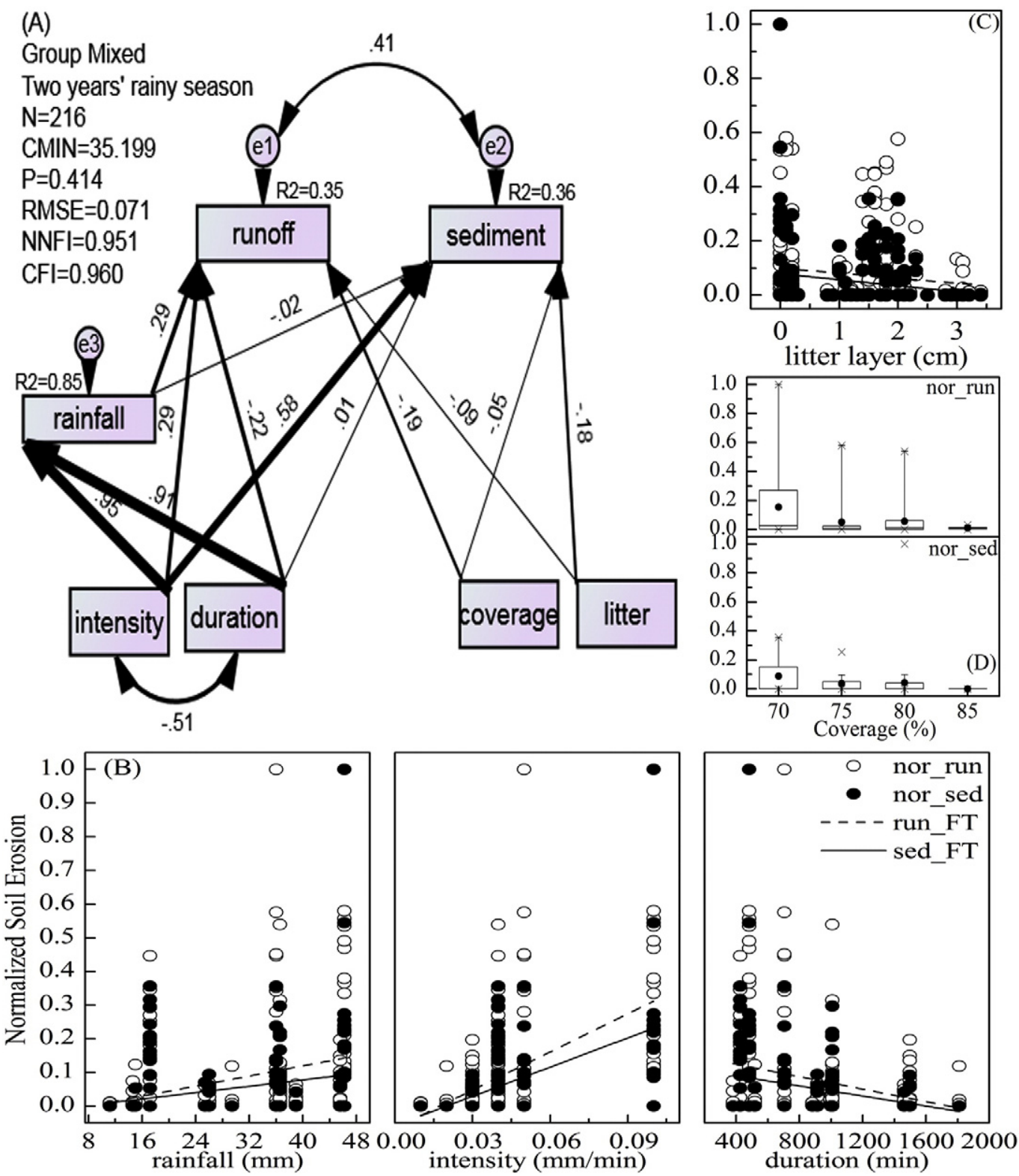

Fig. 6. The same as Fig. 4, except for Group Mixed.

rainfall as the main driving force of runoff and estimated that the threshold rainfall value of runoff generation in abandoned cropland ranged between $2.4 \mathrm{~mm}$ and $4.5 \mathrm{~mm}$. However, the rainfall threshold of runoff could not be determined in our study, and the variance of rainfall threshold of sediment generation explained by the model was also low $\left(R^{2}=0.102\right)$ (Table 5, Group Long). The difference between our study and Liu et al. (2012) might imply that the complicated heterogeneous vegetation patterns in Group Long exerted more complex interactive effects of precipitation and vegetation on hydrological processes in soil matrix systems, which directly affects infiltration (Eldridge et al. 2010) and the source-sink distribution of soil erosion (Puigdefábregas 2005). Specifically, the denser root system in the soil layer $(0-30 \mathrm{~cm})$ of L2 (Fig. 8B) created more macropores in the soil that enhance infiltration along the slope, leading to decreased runoff and sediment transport. In contrast, the lower root distribution at L1 and L3 could probably limit the infiltration capability due to lower hydraulic conductivity (Fig. 9), and increase the potential of runoff generation. Especially, site L3, representing a restoration vegetation dominated by grasses, had neither an obvious canopy structure to intercept rainfall nor a clear litter layer to resist the splashes of raindrops. Therefore, it was at no surprise to find that significantly higher runoff and sediment were yielded at L3 in Group Long (Fig. 3A). Wei et al. (2007) also discovered a similar phenomenon in the Loess Plateau showing relatively higher runoff coefficient and erosion modulus from grassland than from shrubland. The univariate analysis only roughly indicated that the normalized soil erosion decreased with increasing litter layer and coverage (Fig. 4B, C). In contrast, SEM distinctly partitioned the degrees of positive contributions of litter layer and coverage toward soil conservation in the complex restoration vegetation systems. The comparison of univariate and SEM also implied that the path coefficients are more accurate and effective indicators to explore the relationships in a complex system than are univariate regression and correlations (Grace 2006; Larson and Grace 2004). Consequently, soil erosion in Group Long was generally mediated by the interactive actions between the litter layer's inhibition and rainfall splash erosion, as well as by the various root systems directly impacting the hydrological behavior of water such as the infiltration processes in the soil matrix. 

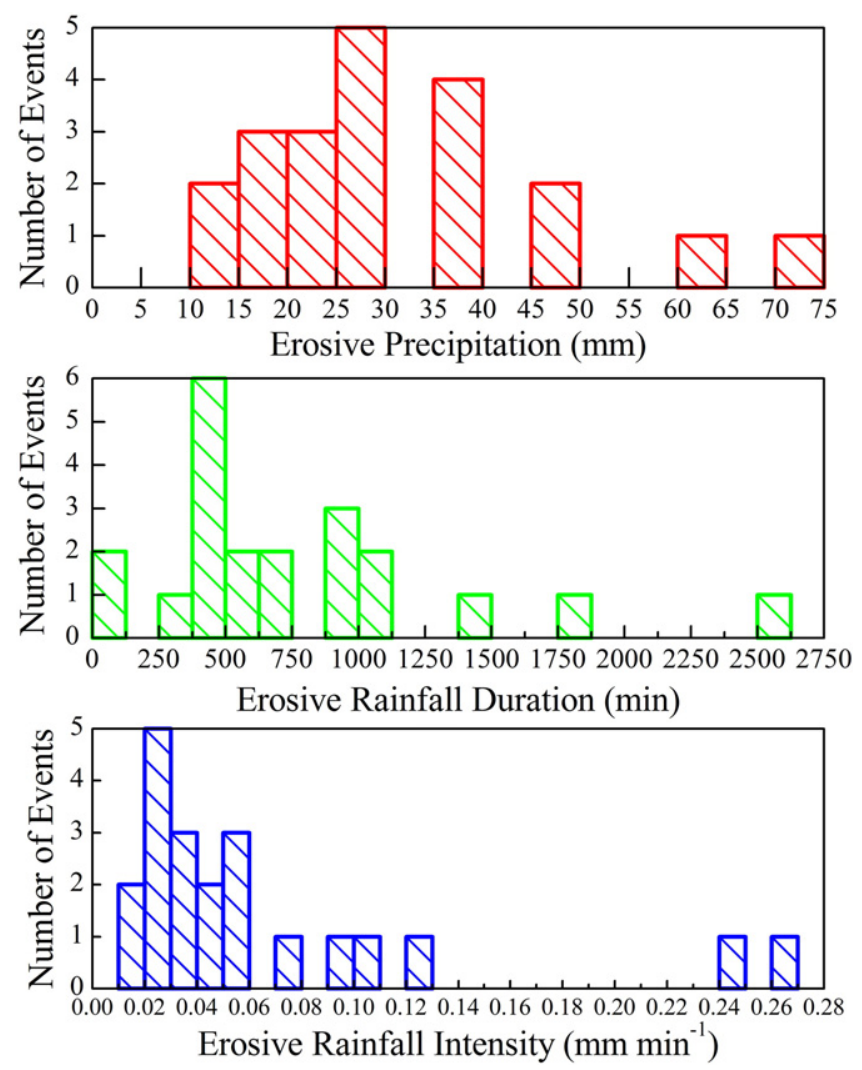

Fig. 7. The distributional characteristics of precipitation, duration and intensity of rainfall events over four rainy seasons.

The restoration vegetation in Group Short (L4-L6) was dominated by shrubs with moderate canopy structure and litter layer thickness (Table 1). Therefore, the morphological properties of plant community, especially the canopy property, indicated lower heterogeneity than those in Group Long. The erosive precipitation in the Loess Plateau was characterized as rainfall with high intensity falling in a relatively short duration, and the intensity was regarded as the most vital indicator for evaluating the extent of soil erosion (Wei et al. 2007). However, SEM from Group Short demonstrated that the combination of precipitation and intensity jointly played the most crucial role on triggering soil erosion, and average coverage exerted a stronger positive effect on controlling soil erosion than litter layer thickness (Fig. 5A). This implied that in the relatively simple plant community system the hydrological function of canopy structure in shrubland during precipitation processes mediates runoff and soil erosion from mainly two perspectives. First, the positive correlation between interception capacity and canopy coverage defines the water storage function of the canopy (Liu 1998; Wang et al. 2012), which can affect the water budget of Group Short sites. Second, the negative effects of canopy cover and plant height on splash erosion provides the cushion erosion function of the canopy structure (Morgan 2001), which depend on rainfall intensity and canopy coverage. The rainfall threshold of runoff in Group Short was approximately $9 \mathrm{~mm}$, which was two times greater than the results of Liu et al. (2012) (Table 5). The difference might be caused by the lower average plant coverage in the latter research $(<30 \%)$, which probably did not have enough canopy structure to intercept precipitation and protect the soil from erosion. Additionally, the lack of significant difference in infiltration capacity between the sites in Group Short (L4-L6) (Fig. 9) could probably be related to the relatively homogeneous and simple plant community structure across the sites. SEM supplied more information than univariate regression (Fig. 5) for Group Short. The coverage has stronger inhibition of runoff and sediment yield than the thickness of the litter layer.

The closed runoff-plot design and the length of the monitoring period could probably be potential factors to cause the variation of erosive responses between Group Long and Group Short. The closed pattern design could prevent outside material from being transported into the closed runoff-plot, and gradually lead to the exhaustion of transportable soil materials in the runoff-plot. As a result, it may become increasingly difficult for the sediment to be generated in the closed runoff-plot under the same erosive precipitation conditions as the monitoring effort advances in time (Boix-Fayos et al. 2006; Ollesch and Vacca 2002). We found no significant difference in sediment yield between Group Long and Group Short. However, the higher threshold values of rainfall intensity of sediment generation at L1 and L2 might imply a higher minimum value of intensity triggering the erosive response (Descheemaeker et al. 2006) at the sites with relatively longer monitoring (Table 5).

The morphological properties of the plant community in Group Mixed had the highest heterogeneity among the three groups, with all sites (L1-L6) included in this group. SEM suggested that rainfall intensity was the prime positive factor affecting runoff and sediment generation across the sites (Fig. 6A). This is consistent with some research (Assouline and Ben-Hur 2006; Chamizo et al. 2012; Wei et al. 2007) showing strong positive correlation between rainfall intensity and runoff coefficients. Furthermore, that the average coverage exerted a stronger negative effect on runoff yield through the interception of canopy structure in Group Mixed was stressed by the SEM. The litter layer thickness on preventing sediment generation in Group Mixed through cushioning splash erosion was also emphasized by SEM. As a result, the SEM in Group Mixed not only indicated that both the coverage and the litter layer played vital roles on soil erosion control but also specified their relative contributions in runoff and sediment yield. The highest morphological heterogeneity of restoration vegetation in Group Mixed

Table 5

Rainfall threshold for runoff and sediment generation of all restoration vegetation.

\begin{tabular}{|c|c|c|c|c|c|c|c|c|}
\hline \multirow{2}{*}{$\begin{array}{l}\text { Restoration } \\
\text { vegetation }\end{array}$} & \multirow{2}{*}{$\begin{array}{l}\text { Sample } \\
\text { size }\end{array}$} & \multirow{2}{*}{$\begin{array}{l}\text { Threshold } \\
\text { parameters }\end{array}$} & \multicolumn{3}{|c|}{ Threshold values of runoff generation } & \multicolumn{3}{|c|}{ Threshold values of sediment generation } \\
\hline & & & Threshold value & $\mathrm{R}^{2}$ & $\mathrm{P}$ & Threshold value & $\mathrm{R}^{2}$ & $\mathrm{P}$ \\
\hline L1 & 63 & Int $^{\mathrm{a}}(\mathrm{mm} / \mathrm{min})$ & 0.017 & 0.123 & 0.000 & 0.025 & 0.279 & 0.000 \\
\hline L2 & 63 & Int & 0.015 & 0.113 & 0.000 & 0.022 & 0.208 & 0.000 \\
\hline L3 & 63 & Int & 0.015 & 0.178 & 0.000 & 0.020 & 0.215 & 0.000 \\
\hline L4 & 36 & Int & 0.017 & 0.262 & 0.000 & 0.019 & 0.630 & 0.000 \\
\hline L5 & 36 & Int & 0.014 & 0.323 & 0.000 & 0.018 & 0.445 & 0.000 \\
\hline L6 & 36 & Int & 0.015 & 0.405 & 0.000 & 0.018 & 0.363 & 0.000 \\
\hline Group Long & 189 & $\operatorname{Pre}^{\mathrm{b}}(\mathrm{mm}) / \mathrm{Int}$ & $x^{c} / 0.016$ & $\times / 0.125$ & $\times / 0.000$ & $22.2 / 0.02$ & $0.102 / 0.176$ & 0.001 \\
\hline Group Short & 108 & Pre/Int & $8.86 / 0.015$ & $0.124 / 0.523$ & 0.000 & $\times / 0.018$ & $\times / 0.487$ & 0.000 \\
\hline Group Mixed & 216 & Pre/Int & $\times / 0.019$ & $\times / 0.292$ & 0.001 & $\times / 0.021$ & $\times / 0.312$ & 0.000 \\
\hline
\end{tabular}

\footnotetext{
a Short for rainfall intensity.

b Short for precipitation.

c There is no corresponding threshold value.
} 
(A)

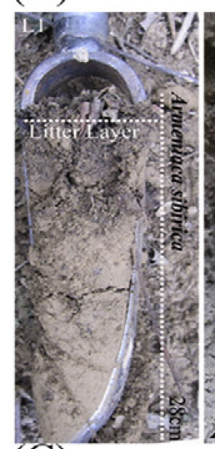

(C)

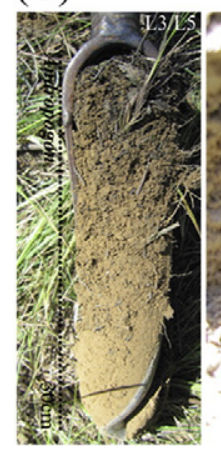

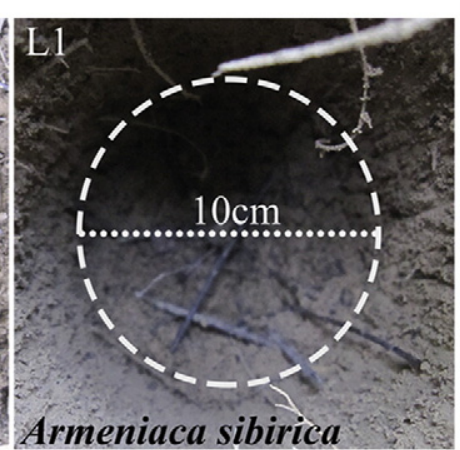

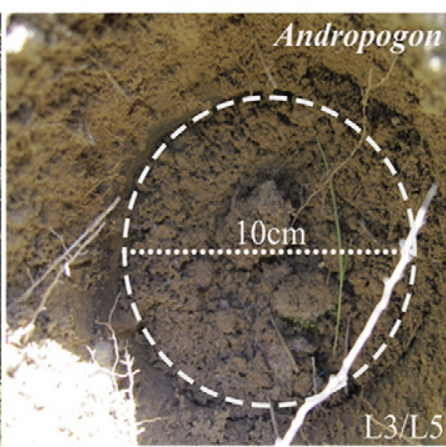

(B)

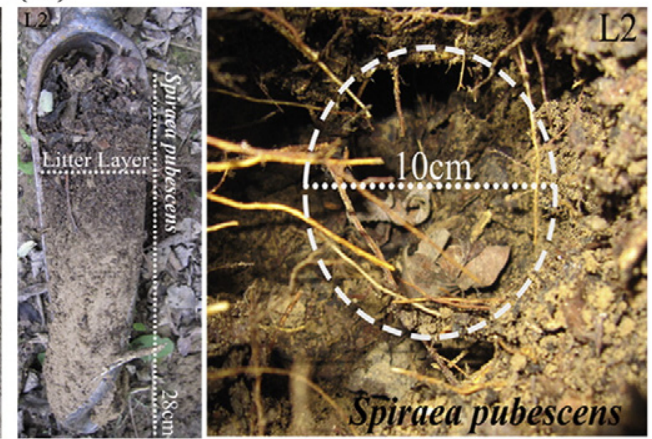

(D)

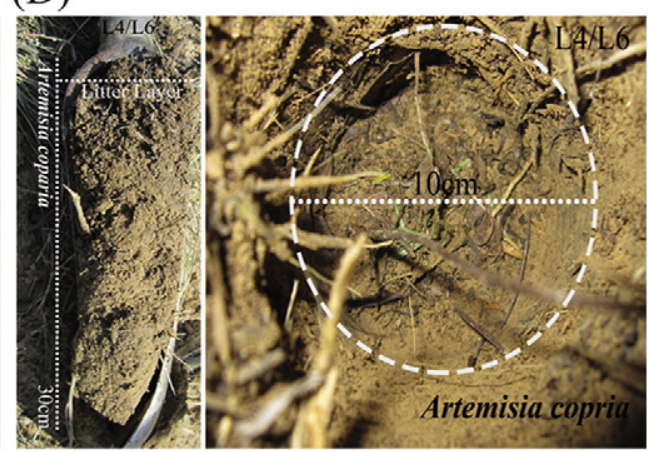

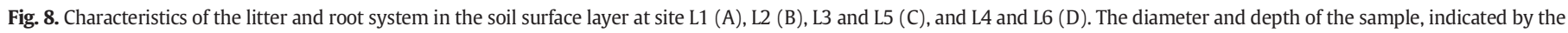
dashed circle, were approximately $10 \mathrm{~cm}$ and $15 \mathrm{~cm}$, respectively.

was probably the main reason for more complex vegetation impact on soil erosion. Jost et al. (2012) also showed that vegetation species with the same soil conditions could lead to different hydrological responses such as runoff generation or soil water distribution. Heterogeneous vegetation patterns, to some degree, could have stronger interception and cushion erosion capacity than simple patterns, eventually reducing the risk of soil erosion generation (Buttle and Farnsworth 2012; Comino and Druetta 2010). This was reflected specifically at L2 characterized by a moderate height shrub, thick litter layer, and dense root system. Such a shrub-dominated system could effectively prevent splash erosion, improve infiltration, and finally decrease the runoff and sediment yield. In contrast, the canopies were low and incomplete with a thin litter layer and low infiltration rate at the grassland sites (L3 and L5). It indicated that restoration with grasses was more susceptible to erosion in the Loess Plateau, consistent with previous observations (El Kateb et al. 2013; Wei et al. 2007).

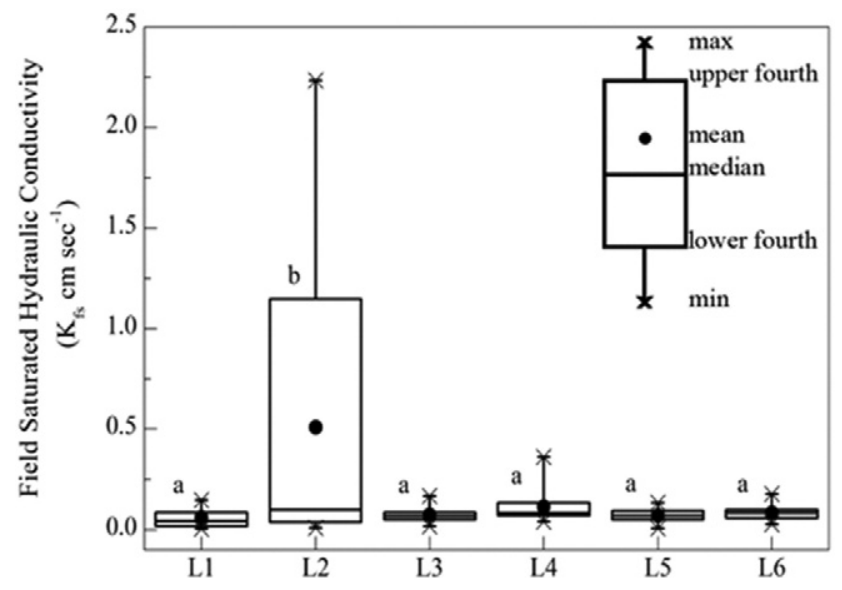

Fig. 9. The distribution of saturated hydraulic conductivity $\left(\mathrm{K}_{\mathrm{fs}}\right)$ measured at individual sites. Insert shows the meanings of the quantile boxplot.

\section{Conclusion}

This study systematically analyzed the interactive effects of precipitation and vegetation on soil erosion under different restored vegetation covers in the Loess Plateau. At sites with high heterogeneity in canopy structure (Group Long), erosive precipitation and average thickness of the litter layer exerted positive and negative effects on soil erosion, respectively. At sites with low heterogeneity in plant patterns (Group Short), erosive responses were positively impacted by the combination of erosive rainfall precipitation and intensity, and negatively influenced by the average coverage of vegetation. After pooling all sites together (Group Mixed), the average vegetation coverage and litter layer exerted negative impacts on runoff and sediment yield, and erosive rainfall intensity became the most crucial triggering force to soil erosion. SEM analysis revealed more information on the effects of precipitation and vegetation on soil erosion than the traditional univariate regression and correlation analysis. The problem-oriented SEM method should be applied more in future soil erosion studies.

\section{Acknowledgements}

This work was funded by the National Natural Science Foundation of China (No.41390464 and 41101096). We also appreciate the editor and anonymous reviewers' supports and comments.

\section{References}

Assouline, S., Ben-Hur, M., 2006. Effects of rainfall intensity and slope gradient on the dynamics of interrill erosion during soil surface sealing. Catena 66, 211-220.

Austin, M., 2007. Species distribution models and ecological theory: a critical assessment and some possible new approaches. Ecol. Model. 200, 1-19.

Bautista, S., Mayor, A.G., Bourakhouadar, J., Bellot, J., 2007. Plant spatial pattern predicts hillslope runoff and erosion in a semiarid Mediterranean landscape. Ecosystems 10, 987-998.

Bentler, P.M., Bonet, D.G., 1980. Significance tests and goodness of fit in the anaylsis of covariance structure. Psychometrika 45, 289-308.

Bentler, P.M., Yuan, K.H., 1999. Structural equation modeling with small samples: test statistics. Multivar. Behav. Res. 34, 181-197. 
Bodí, M.B., Doerr, S.H., Cerdà, A., Mataix-Solera, J., 2012. Hydrological effects of a layer of vegetation ash on underlying wettable and water repellent soil. Geoderma 191, 14-23.

Boix-Fayos, C., Martínez-Mena, M., Arnau-Rosalén, E., Calvo-Cases, A., Castillo, V., Albaladejo, J., 2006. Measuring soil erosion by field plots: understanding the sources of variation. Earth Sci. Rev. 78, 267-285.

Burylo, M., Hudek, C., Rey, F., 2011. Soil reinforcement by the roots of six dominant species on eroded mountainous marly slopes (Southern Alps, France). Catena 84, 70-78.

Buttle, J.M., Farnsworth, A.G., 2012. Measurement and modeling of canopy water partitioning in a reforested landscape: the Ganaraska Forest, southern Ontario. J. Hydrol. 466-467, 103-114.

Cerdà, A., Doerr, S.H., 2008. The effect of ash and needle cover on surface runoff and erosion in the immediate post-fire period. Catena 74, 256-263.

Chamizo, S., Cantón, Y, Rodríguez-Caballero, E., Domingo, F., Escudero, A, 2012. Runoff a contrasting scales in a semiarid ecosystem: a complex balance between biological soil crust features and rainfall characteristics. J. Hydrol. 452-453, 130-138.

Comino, E., Druetta, A., 2010. The effect of Poaceae roots on the shear strength of soils in the Italian alpine environment. Soil Tillage Res. 106, 194-201.

Curran, J.C., Hession, W.C., 2013. Vegetative impacts on hydraulics and sediment processes across the fluvial system. J. Hydrol. 505, 364-376.

Descheemaeker, K., Nyssen, J., Poesen, J., Raes, D., Haile, M., Muys, B., Deckers, S., 2006. Runoff on slopes with restoring vegetation: a case study from the Tigray highlands. J. Hydrol. 331, 219-241.

El Kateb, H., Zhang, H., Zhang, P., Mosandl, R., 2013. Soil erosion and surface runoff on different vegetation covers and slope gradients: a field experiment in Southern Shaanxi Province. Catena 105, 1-10.

Eldridge, D.J., Bowker, M.A., Maestre, F.T., Alonso, P., Mau, R.L., Papadopoulos, J., Escudero, A., 2010. Interactive effects of three ecosystem engineers on infiltration in a semi-arid Mediterranean grassland. Ecosystems 13, 499-510.

Fattet, M., Fu, Y., Ghestem, M., Ma, W., Foulonneau, M., Nespoulous, J., Le Bissonnais, Y., Stokes, A., 2011. Effects of vegetation type on soil resistance to erosion: relationship between aggregate stability and shear strength. Catena 87, 60-69.

Fu, B., Liu, Y., Lü, Y., He, C., Zeng, Y., Wu, B., 2011. Assessing the soil erosion control service of ecosystems change in the Loess Plateau of China. Ecol. Complex. 8, 284-293.

Fu, W., Huang, M., Gallichand, J., Shao, M., 2012. Optimization of plant coverage in relation to water balance in the Loess Plateau of China. Geoderma 173-174, 134-144.

García-Ruiz, J.M., 2010. The effects of land uses on soil erosion in Spain: a review. Catena $81,1-11$.

Geißler, C., Kühn, P., Böhnke, M., Bruelheide, H., Shi, X., Scholten, T., 2012. Splash erosion potential under tree canopies in subtropical SE China. Catena 91, 85-93.

Ghimire, C.P., Bruijnzeel, L.A., Lubczynski, M.W., Bonell, M., 2012. Rainfall interception by natural and planted forests in the Middle Mountains of Central Nepal. J. Hydrol. 475, $270-280$

Grace, J.B., 2006. Structural Equation Modelling and Natural Systems. Cambridge University Press, UK.

Gu, Z.J., Wu, X.X., Zhou, F., Luo, H., Shi, X.Z., Yu, D.S., 2013. Estimating the effect of Pinus massoniana lamb plots on soil and water conservation during rainfall events using vegetation fractional coverage. Catena 109, 225-233.

Gyssels, G., Poesen, J., Bochet, E., Li, Y., 2005. Impact of plant roots on the resistance of soils to erosion by water: a review. Prog. Phys. Geogr. 29, 189-217.

Hartanto, H., Prabhu, R., Widayat, A.S.E., Asdak, C., 2003. Factors affecting runoff and soil erosion: plot-level soil loss monitoring for assessing sustainability of forest management. For. Ecol. Manag. 180, 361-374.

Jost, G., Schume, H., Hager, H., Markart, G., Kohl, B., 2012. A hillslope scale comparison of tree species influence on soil moisture dynamics and runoff processes during intense rainfall. J. Hydrol. 420-421, 112-124.

Kurothe, R.S., Kumar, G., Singh, R., Singh, H.B., Tiwari, S.P., Vishwakarma, A.K., Sena, D.R. Pande, V.C., 2014. Effect of tillage and cropping systems on runoff, soil loss and crop yields under semiarid rainfed agriculture in India. Soil Tillage Res. 140, 126-134.

Lantican, M.A., Guerra, L.G., Bhuiyan, S.I., 2003. Impact of soil erosion in the upper Manupali watershed on irrigated lowlands in the Philippines. Paddy Water Environ. $1,19-26$.
Larson, D.L., Grace, J.B., 2004. Temporal dynamics of leafy spurge (Euphorbia esula) and two species of flea beetles (Aphthona spp.) used as biological control agents. Biol. Control 29, 207-214.

Liu, S., 1997. A new model for the prediction of rainfall interception in forest canopies. Ecol. Model. 99, 151-159.

Liu, S., 1998. Estimation of rainfall storage capacity in the canopies of cypress wetlands and slash pine uplands in North-Central Florida. J. Hydrol. 207, 32-41.

Liu, Y., Fu, B., Lu, Y., Wang, Z., Gao, G., 2012. Hydrological responses and soil erosion potential of abandoned cropland in the Loess Plateau. Geomorphology 138, 404-414.

MacCallum, R.C., Browne, M.W., Sugawara, H.M., 1996. Power analysis and determination of sample size for covariance structure modeling. Psychol. Methods 1, 130-149.

Marques, M.J., Bienes, R., Perez-Rodriguez, R., Jiménez, L., 2008. Soil degradation in central Spain due to sheet water erosion by low-intensity rainfall events. Earth Surf. Process. Landf. 33, 414-423.

Mayor, A.G., Bautista, S., Small, E.E., Dixon, M., Bellot J. 2008. Measurment of the connectivity of runoff source areas as determined by vegetation pattern and topography: a tool for assessing potential water and soil losses in drylands. Water Resour. Res. 44, W10423.

Mohammad, A.G., Adam, M.A., 2010. The impact of vegetative cover type on runoff and soil erosion under different land uses. Catena 81, 97-103.

Molina, A., Vanacker, V., Balthazar, V., Mora, D., Govers, G., 2012. Complex land cover change, water and sediment yield in a degraded Andean environment. J. Hydrol. 472-473, 25-35.

Morgan, R.P.C., 2001. A simple approach to soil loss prediction: a revised Morgan-Finney model. Catena 44, 305-322.

Ollesch, G., Vacca, A., 2002. Influence of time on measurement results of erosion plots studies. Soil Tillage Res. 67, 23-39.

Park, A., Friesen, P., Serrud, A.A.S., 2010. Comparative water fluxes through leaf litter of tropical plantation trees and the invasive grass Saccharum spontaneum in the Republic of Panama. J. Hydrol. 383, 167-178.

Portenga, E.W., Bierman, P.R., 2011. Understanding earth's eroding surface with ${ }^{10} \mathrm{Be}$. GSA Today 21, 4-10.

Price, K., Jackson, C.R., Parker, A.J., 2010. Variation of surficial soil hydraulic properties across land uses in the southern Blue Ridge Mountains, North Carolina. J. Hydrol. 383, 256-268.

Puigdefábregas, J., 2005. The role of vegetation patterns in structuring runoff and sediment fluxes in drylands. Earth Surf. Process. Landf. 30, 133-147.

Puigdefábregas, J., Sole-Benet, A., Gutierrez, L., Del Barrio, G., Boer. M., 1999. Scales and processes of water and sediment redistribution in drylands: results from the Rambla Honda field site in Southeast Spain. Earth Sci. Rev. 48: 39-70.

Renard, K.G., Freimund, J.R., 1994. Using monthly precipitation data to estimate the Rfactor in the revised USLE. J. Hydrol. 157, 287-306.

Rigdon, E., 1995. A necessary and sufficient identification rule for structural equation models estimated. Multivar. Behav. Res. 30, 359-383.

Rodriguez-Iturbe, I., Porporato, A., Laio, F., Ridolfi, L., 2001. Plant in water-controlled ecosystems: active role in hydrologic processes and response to water stress I. Scope and general outline. Adv. Water Resour. 24, 695-705.

Sutton-Grier, A.E., Kenney, M.A., Richardson, C.J., 2010. Examining the relationship between ecosystem structure and function using structural equation modelling: a case study examining denitrification potential in restored wetland soils. Ecol. Model. 221, 761-768.

Texeira, M., Baldi, G., Paruelo, J., 2012. An exploration of direct and indirect drivers of herbivore reproductive performance in arid and semi arid rangelands by means of structural equation models. J. Arid Environ. 81, 26-34.

Wang, X., Zhang, Y., Hu, R., Pan, Y., Berndtsson, R., 2012. Canopy storage capacity of xerophytic shrubs in Northwestern China. J. Hydrol. 454-455, 152-159.

Wei, W. Chen, L., Fu, B., Huang Z., Wu, D., Gui, L., 2007. The effect of land uses and rainfall regimes on runoff and soil erosion in the semi-arid loess hilly area. J. Hydrol. 335, 247-258.

Woods, S.W., Balfour, V.N., 2010. The effects of soil texture and ash thickness on the postfire hydrological response from ash-covered soils. J. Hydrol. 393, 274-286.

Wu, L., 2010. Structural Equation Modeling-The Application and Programing of AMOS. Chongqing University Press, China. 